\title{
A KINETIC STUDY OF ESTERIFICATION OF NAPHTHENIC ACIDS FROM A COLOMBIAN HEAVY CRUDE OIL
}

\author{
Haydée Quiroga-Becerra ${ }^{1 *}$, Carlos Mejía-Miranda ${ }^{1}$, Dionisio Laverde-Cataño ${ }^{2}$, \\ Marian Hernández-López² and Mauricio Gómez-Sánchez² \\ 1Ecopetrol S.A. - Instituto Colombiano del Petróleo (ICP), A.A. 4185 \\ Bucaramanga, Santander, Colombia \\ 2Universidad Industrial de Santander, Bucaramanga, Santander, Colombia \\ e-mail: haydee.quiroga@ecopetrol.com.co
}

(Received Dec. 09, 2011 ; Accepted May 10, 2012)

\section{ABSTRACT}

his article presents the kinetic study of the esterification reaction of naphthenic acids from a Colombian heavy crude oil, with a Total Acid Number (TAN) of 7,33 $\mathrm{mgKOH} / \mathrm{g}$, in a batch type reactor. Temperature was changed between $150-250^{\circ} \mathrm{C}$ while the ratio moles of methanol per mole of carboxylic groups, remained constant in 20:1. The reaction time was varied from $0-600$ minutes. Reduction in the concentration of naphthenic acids in the reactor is determined by the measurement of Number Total Acid (TAN), ASTM D 664. Naphthenic acids were extracted from the crude and structurally characterized by Fourier Transform Infrared Spectroscopy (FTIR), Nuclear Magnetic Resonance (NMR) and Gel Permeation Chromatography (GPC).

The esterified oil was analyzed by FTIR, to identify the variation of the main functional groups. After determining the activation energy, frequency factor and, reaction order, a kinetic law was proposed for the esterification of naphthenic acids in Colombian heavy oil. Finally, it was evaluated the effect of esterification of naphthenic acids on the corrosion of steel ASTM A106 Gr.B. The corrosion of steel was reduced from 34, 16 to 3,08 mils per year, (mpy), after esterification of naphthenic acids.

Keywords: Esterification, Naphthenic acid, Heavy crudes, Acidity, Corrosion.

Citation: Quiroga-Becerra, H., Mejía-Miranda, C., Laverde-Cataño, D., Hernández-López, M. \& Gómez-Sánchez, M. (2012). A kinetic study of esterification of naphthenic acids from a Colombian heavy crude oil. CT\&F - Ciencia, Tecnología y Futuro, 4 (5), $21-32$.

*To whom correspondence should be addressed 


\section{RESUMEN}

E n este artículo se presenta el estudio cinético de la reacción de esterificación de los ácidos nafténicos de un crudo pesado colombiano, con un Número Total Ácido (TAN) de 7,33 mgKOH/g, en un reactor de mezcla completa en operación por lotes. La temperatura de reacción se varió entre $150-250^{\circ} \mathrm{C}$, y el tiempo entre 0 - 600 minutos. La reacción se llevó a cabo con un exceso molar de metanol de 20 moles por cada mol del grupo carboxílico. Los ácidos nafténicos fueron extraídos del crudo de alta acidez y caracterizados estructuralmente mediante Espectroscopia de Infrarrojo con Transformada de Fourier (FTIR), Resonancia Magnética Nuclear (RMN) y Cromatografía de Permeación en Gel (GPC).

Se evaluó la reducción de la acidez del crudo esterificado por titulación potenciométrica siguiendo la norma ASTM D 664. El crudo esterificado fue analizado con FTIR, con el fin de identificar la variación de los principales grupos funcionales. A partir de la determinación de la energía de activación, el factor de frecuencia y el orden de la reacción, se propuso la ley de velocidad para la esterificación de ácidos nafténicos de un crudo pesado colombiano, en un reactor de mezcla completa en operación por lotes. La cinética de esterificación se ajustó a una ley de velocidad de segundo orden con respecto a la concentración de ácidos nafténicos. La energía de activación de la reacción de esterificación fue calculada en 72,27 kJ/mol. Finalmente, se evaluó el efecto de la esterificación de los ácidos nafténicos del crudo pesado sobre la corrosión de un acero ASTM A106Gr.B. La velocidad de corrosión del acero disminuyó de 34,16 a 3,08 milésimas de pulgada por año (mpy), después de la esterificación de los ácidos nafténicos.

Palabras clave: Esterificación, Ácidos nafténicos, Crudos pesados, Acidez, Corrosión.

\section{RESUMO}

$\mathbf{N}$

este artigo apresenta-se o estudo cinético da reação de esterificação dos ácidos naftênicos de um cru pesado colombiano, com um Número Total Ácido (TAN) de 7,33 $\mathrm{mgKOH} / \mathrm{g}$, em um reator de mistura completa em operação por lotes. A temperatura de reação variou-se entre $150-250^{\circ} \mathrm{C}$, e o tempo entre 0 - 600 minutos. A reação realizou-se com um excesso molar de metanol de 20 moles por cada mol do grupo carboxílico. Os ácidos naftênicos foram extrá́dos do cru de alta acidez e caracterizados estruturalmente mediante Espectroscopia de Infravermelho com Transformada de Fourier (FTIR), Ressonância Magnética Nuclear (RMN) e Cromatografia de Permeação em Gel (GPC).

Avaliou-se a redução da acidez do cru esterificado por titulação potenciométrica seguindo a norma ASTM D 664. O cru esterificado foi analisado com FTIR, com a finalidade de identificar a variação dos principais grupos funcionais. A partir da determinação da energia de ativação, o fator de frequência e a ordem da reação, propôs-se a lei de velocidade para a esterificação de ácidos naftênicos de um cru pesado colombiano, em um reator de mistura completa em operação por lotes. A cinética de esterificação ajustou-se a uma lei de velocidade de segunda ordem com relação à concentração de ácidos naftênicos. A energia de ativação da reação de esterificação foi calculada em 72,27 kJ/mol. Finalmente, avaliou-se o efeito da esterificação dos ácidos naftênicos do cru pesado sobre a corrosão de um aço ASTM A106 Gr.B. A velocidade de corrosão do aço diminuiu de 34,16 a 3,08 milésimas de polegada por Ano (mpy), depois da esterificação dos ácidos naftênicos.

Palavras chave: Esterificação, Ácidos naftênicos, Crus pesados, Acidez, Corrosão. 


\section{INTRODUCTION}

Corrosion problems in refinery equipment arise during the processing of high acidity crude oils. Corrosion due to naphthenic acids occurs at temperatures between 200 and $400^{\circ} \mathrm{C}$ and primarily affects the transfer pipes between the heating furnaces and atmospheric and vacuum distillation units (Qu \& Zheng, 2006). Thermal decomposition of the naphthenic acids becomes significant at temperatures above $400^{\circ} \mathrm{C}$, therefore generating corrosion problems are not evident over that temperature (Kane \& Cayard, 2002).

Acids from oil consist primarily of monocarboxylic acids, including aliphatic, naphthenic, and aromatic acids. Naphthenic acids are predominantly found in immature heavy crudes due to the fact that they come from the biodegradation in petroleum hydrocarbon reservoirs (Biryukova, Fedorak \& Quideau, 2007). Acidity of crude oil is associated with de TAN, and it is expressed in milligrams $\mathrm{KOH}$ necessary in order to neutralize one gram of crude. Crude oils with acidity levels above $0,5 \mathrm{mgKOH} / \mathrm{g}$ are considered potentially corrosive for refinery units (Alvisi \& Lins, 2011; Dettman, Li, Luo \& Wickramasinghe, 2010). Aside from the corrosive effect, naphthenic acids lead to formation of stable emulsions by forming metallic naphthenates that reduce interfacial tension, affecting the processes that involve phase separation stages (Ding et al., 2009). Additionally, calcium naphthenates precipitate along the preheating train and furnaces, promoting coke formation (Simon, Nordgård, Bruheim \& Sjöblom, 2008).

Naphthenic acid removal is one of the most important aspects in safe processing of opportunity crudes. The study and implementation of naphthenic acid removal processes is of vital importance for the adequate exploitation of Colombian heavy crude oil reserves containing high acidity. Investigations regarding acidity reduction in crudes include non-destructive processes such as solvent extraction and adsorption (Wang et al., 2006; Gaikar \& Maiti, 1996).

Solvent extraction leads to the generation of excessive quantities of secondary industrial wastewater. Additionally, water/crude emulsions of difficult separation are generated during the process (Ding et al., 2009).
Adsorption using ionic exchange resins or other adsorbent materials such as clays may only be applied when dealing with light crudes and light distillation fractions.

Thermal and catalyst decarboxylation of naphthenic acids is an alternative for the processing of high acidity crudes (Zhang et al., 2006; Ding et al., 2009). However, in order to obtain noticeable reduction percentages, it is necessary to operate at temperatures above $250^{\circ} \mathrm{C}$, which could lead to corrosion problems in these units. Esterification is a promising alternative for safe processing of these types of opportunity crudes because it is possible to reach significant acidity reduction percentages at temperatures below $250^{\circ} \mathrm{C}$ even in the absence of a catalyst (Sartori, 2001).

Some studies concerning acid reduction through esterification have been performed with light distillation currents and obtained satisfactory results. Wang, Sun, Liu and Liu (2007) used $\mathrm{SnO} / \mathrm{Al}_{2} \mathrm{O}_{3}$ as a catalyst for the esterification of a diesel current, obtaining an acidity reduction from 1,7 to less than $0,1 \mathrm{mg} \mathrm{KOH} / \mathrm{g}$. The tests were performed using a fixed bed reactor, a methanol/crude ratio of 0,010 ; and an optimum reaction temperature of $280^{\circ} \mathrm{C}$.

Wang, Liu and Liu (2008) performed a kinetic study of the esterification reaction of naphthenic acids in a diesel fuel. The study was carried out in a dynamic autoclave and aimed to evaluate the influence of the presence of $\mathrm{SnO}$ catalyst upon the reaction's kinetic parameters. Due to the differences in the concentration and molecular structure of acids between crudes, the kinetic reactions for esterification must be determined for each type of crude.

The purpose of this study was to determine the kinetics of esterification naphthenic acids in Colombian heavy crude oil of high acidity in the absence of a catalyst. The effects of the presence of a catalyst in the esterification reaction were not quantified in order to establish the reference values under experimental conditions for further study.

Finally, the effects of the esterification of acids in relation to corrosion reduction rates for carbon steel were evaluated. 


\section{EXPERIMENTAL METHODOLOGY}

Colombian heavy crude oil of high acidity was used in this kinetic study. The basic physical-chemical properties are established in Table 1.

Table 1. Basic physical-chemical properties of Colombian heavy crude oil of high acidity.

\begin{tabular}{|l|l|l|}
\hline $\begin{array}{l}\text { Property } \\
\text { TAN } \\
\mathrm{mg} \mathrm{KOH} / \mathrm{g}\end{array}$ & Standard & Result \\
\hline API at $15,6^{\circ} \mathrm{C}$ & ASTM D 664 & 7,33 \\
\hline Sulfur $(\% \mathrm{~W})$ & ASTM D 287 & 11,3 \\
\hline Density at $15^{\circ} \mathrm{C}, \mathrm{g} / \mathrm{cm}^{3}$ & ASTM D 1552 & 1,552 \\
\hline
\end{tabular}

\section{Extraction of Naphthenic Acids}

The extraction method used was the solvent extraction method proposed in literature (Hoeiland, Barth, Blokhus \& Skauge, 2001; dos Santos, Mohamed, Bannwart \& Loh, 2006). Approximately $100 \mathrm{~mL}$ of crude is dissolved in light naphtha at a rate of 1:1 by volume. Three consecutive washes are performed using an aqueous solution of $1 \mathrm{M} \mathrm{NaOH}$. The aqueous solution containing the salts of the naphthenic acids is washed with hexane, in order to remove the remaining traces of hydrocarbons from the first stage of contact. The aqueous solution is then acidified up to $\mathrm{pH}<2$ using $\mathrm{HCl}$. The extraction of naphthenic acids is obtained by successive washes using dicloromethane. Finally, the dicloromethane solution is dried out using calcium carbonate as a molecular sieve. The dicloromethane is then evaporated and the acid fraction is obtained and characterized.

\section{Structural Characterization of the Obtained Acidic Fraction}

The extracted naphthenic acids were analyzed through infrared spectroscopy using a SHIMADZU $8400 S$, in order to identify and monitor the representative functional groups in the acidic fraction. The distribution of the molecular weight in the acidic fraction was determined by GPC in a Waters 2414 refractive index detector, at a column temperature of $40^{\circ} \mathrm{C}$, mobile phase, Tetrahydrofuran (THF). Additionally, the naphthenic acids underwent a proton NMR analysis in a BRUKER $400 \mathrm{MHz}$ spectrometer using deuterateddicloromethane as solvent.

\section{Kinetics of the Esterification of Naphthenic Acids}

The kinetic study of esterification was performed in a Hastelloy C276, Parr Instruments reactor, with a total capacity of $2000 \mathrm{~mL}$. The tests were performed at $150 ; 200$ and $250^{\circ} \mathrm{C}$. The reaction time varied between 0 - 600 minutes and the agitation speed was $600 \mathrm{rpm}$. The reactor was loaded with $1200 \mathrm{~mL}$ of heavy crude and Merck anhydrous methanol at a molar rate of 20:1 alcohol per mol of carboxylic group. A catalyst was not used during this kinetic study.

After each reaction, the reactor was taken to $100^{\circ} \mathrm{C}$ and maintained at that temperature for a period of six hours in order to remove any remaining methanol. In order to establish the acidity reduction percentage, the TAN in the treated crude was determined per ASTM D 664 .

The infrared analysis was then carried out for the esterified crude at $150 ; 200$ and $250^{\circ} \mathrm{C}$ and after 600 minutes reaction time in order to verify that the reduction in the TAN of the crude after treatment was due to the formation of esters.

\section{Evaluation of the Corrosiveness of the Esterified Crude}

The objective of this experimental stage was to determine the effects of acidity reduction due to esterification of naphthenic acids as measured of carbon steel cuopons through the weight loss measurement technique ASTM G1. The tests were performed in a Hastelloy 4572 dynamic autoclave by Parr Instruments, at $300^{\circ} \mathrm{C}$, during 480 minutes of exposure.

According to the agitation conditions, the physicalchemical properties of the fluid and the internal dimensions of the reactor, the corrosion tests were carried out with a shear stress of $3,78 \mathrm{~m} \cdot \mathrm{kg} / \mathrm{s}^{2}$ on the material surface. 


\section{RESULTS AND ANALYSIS}

The infrared spectrum of the extracted acidic fraction is shown in Figure 1. An intense band is observed at $1705 \mathrm{~cm}^{-1}$ which corresponds to the stretching of the $C=O$ group in the carboxylic acids and a band between 2500 and $3500 \mathrm{~cm}^{-1}$ which corresponds to tension vibration of the $\mathrm{O}-\mathrm{H}$ group associated to the acidic function. The absorption due to out-of-plane bending of the $\mathrm{OH}$ bond produces the band observed at $945 \mathrm{~cm}^{-1}$.

The asymmetric and symmetric stretching of the $\mathrm{CH}_{2}$ methylene groups is shown at 2924 and $2866 \mathrm{~cm}^{-1}$, respectively. The signal at $1377 \mathrm{~cm}^{-1}$ corresponds to outof-plane bending of the $\mathrm{C}-\mathrm{O}-\mathrm{H}$ group, a characteristic of carboxylic acids. The signal corresponding to $\mathrm{C}-\mathrm{O}$ bond stretching is observed at $1265 \mathrm{~cm}^{-1}$. The signals corresponding to the vibrations of the methylene group are shown at 1378 and $1472 \mathrm{~cm}^{-1}$. The band corresponding to vibration balancing of the $\mathrm{CH}_{2}$ group at $720 \mathrm{~cm}^{-1}$, indicates the presence of this group in carbon chains of more than 4 carbons. The $C=C$ absorption stretching in aromatic bonds was not observed between $1595-1620$ $\mathrm{cm}^{-1}$. The band corresponding to the presence of aromatics generally presents low intensity which could make its identification by means of infrared spectroscopy difficult (Rikka, 2007).

The average molecular weight, $M_{W}$, determined from the information obtained from the GPC was 405 $\mathrm{g} / \mathrm{mol}$. The polydispersity index was: 1,18 . The average molecular weight for the extracted acidic fraction cor-

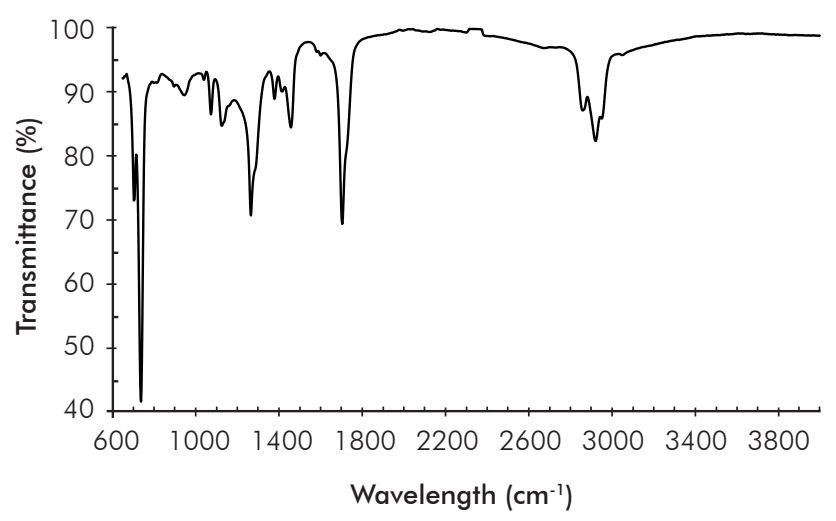

Figure 1. Infrared spectrum of the acidic fraction extracted from the Colombian heavy crude oil. responds to the value determined by Borges and Acevedo (2007), $418 \mathrm{~g} / \mathrm{mol}$, for an acidic fraction soluble in heptanes for extra-heavy crude from Carabobo. The molecular weight distribution for the extracted acidic fraction is presented in Figure 2.

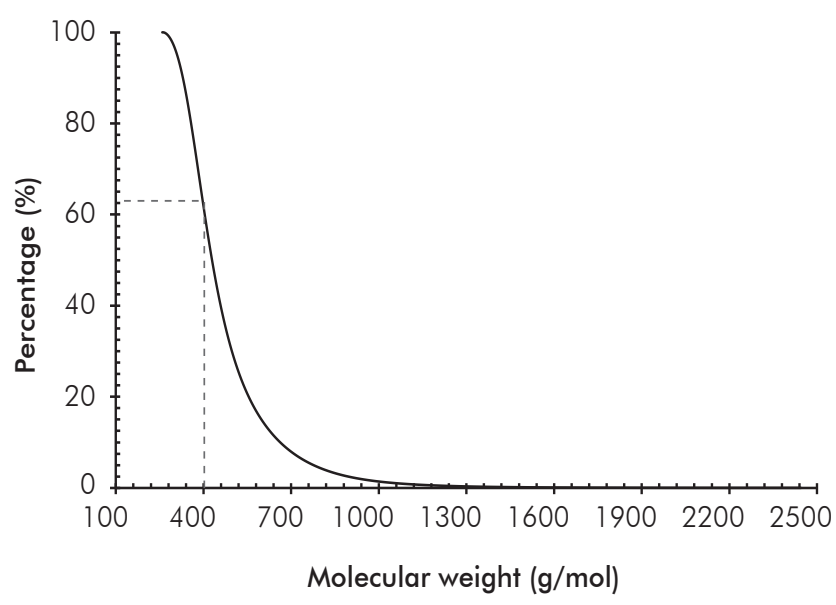

Figure 2. Molecular weight distribution of the naphthenic acids extracted from the Colombian heavy crude oil.

The naphthenic acids extracted from the Colombian heavy crude oil present a molecular weight interval between $180-2400 \mathrm{~g} / \mathrm{mol}$. According to Dettman et al., (2010), the structural characteristics of the naphthenic acids significantly influence corrosion rates in materials. Messer, Beaton, Tarleton and Phillips (2004), proposed that the corrosive effect of naphthenic acids could be classified according to the distribution of their molecular weight, considering any fraction below $400 \mathrm{~g} / \mathrm{mol}$ as highly corrosive; and the other fraction as non-corrosive or inhibiting in some cases. $60 \%$ by weight of the extracted fraction of the Colombian heavy crude oil has molecular weights above $400 \mathrm{~g} / \mathrm{mol}$. From the average molecular weight of the acidic fraction and the TAN for the crude, it was estimated that the fraction corresponds to aproximately $5,31 \%$ by weight of the crude.

The molar balance was performed for the distillation cuts of the high acidity crude while aiming to determine the molar distribution of the naphthenic acids (Table 2 ). The thermal decomposition of the naphthenic acids, occurring at temperatures above $300^{\circ} \mathrm{C}$ was evidenced due to molar losses in the carboxylic groups. 
Table 2. Molar distribution of the naphthenic acids in the atmospheric distillation cuts of the Colombian heavy crude oil.

\begin{tabular}{|l|l|}
\hline Cut & Moles COOH (\%) \\
\hline PIE-199 $\mathrm{C}$ & 0,00 \\
\hline $199-250^{\circ} \mathrm{C}$ & 0,03 \\
\hline $250-315^{\circ} \mathrm{C}$ & 1,77 \\
\hline $315-371^{\circ} \mathrm{C}$ & 12,26 \\
\hline$+371^{\circ} \mathrm{C}$ & 53,98 \\
\hline Thermal decomposition & 31,96 \\
\hline
\end{tabular}

Figure 3 presents the proton nuclear magnetic resonance of the extracted acid fraction. The signal corresponding to hydrogen in the carboxyl group is observed at approximately $\delta: 10,97 \mathrm{ppm}$. The hydrogen in the dicloromethane molecule, used as solvent, presented itself at 5,47 ppm. The chemical displacement signal observed between $6,2-9,0 \mathrm{ppm}$, indicates that the naphthenic acid molecules contain an aromaticity of $8,95 \%$. The intensity of the signal between $0-3,0$ ppm indicates the presence of $\mathrm{CH}_{3}$ and $\mathrm{CH}_{2}$ in aliphatic chains and naphthenic rings.

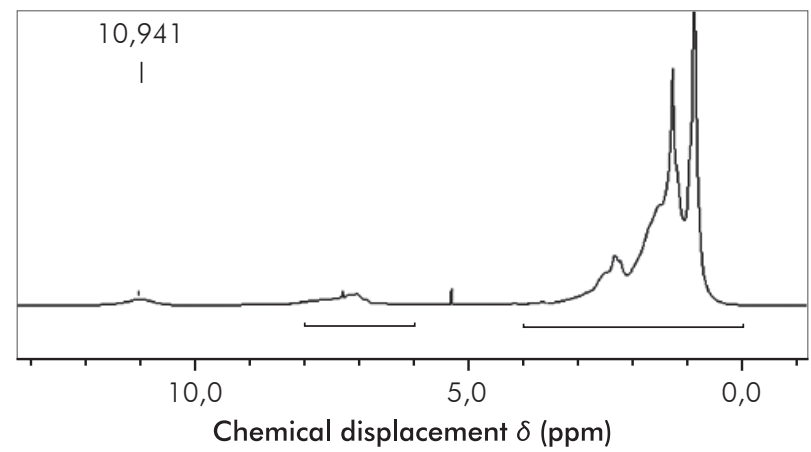

Figure 3. Proton RMN spectrum of the acidic fraction extracted from the Colombian heavy crude oil.

Figure 4 presents the conversion results obtained from the esterification reaction of the naphthenic acids. The increase in acid reduction percentage with the increase of temperature indicates that the esterification reaction is endothermic.

The infrared spectrums presented in Figure 5 show the acidity reduction due to ester formation. The spectrums show a reduction in the carboxyl group band, $1705-1710 \mathrm{~cm}^{-1}$, stretching $C=O$.

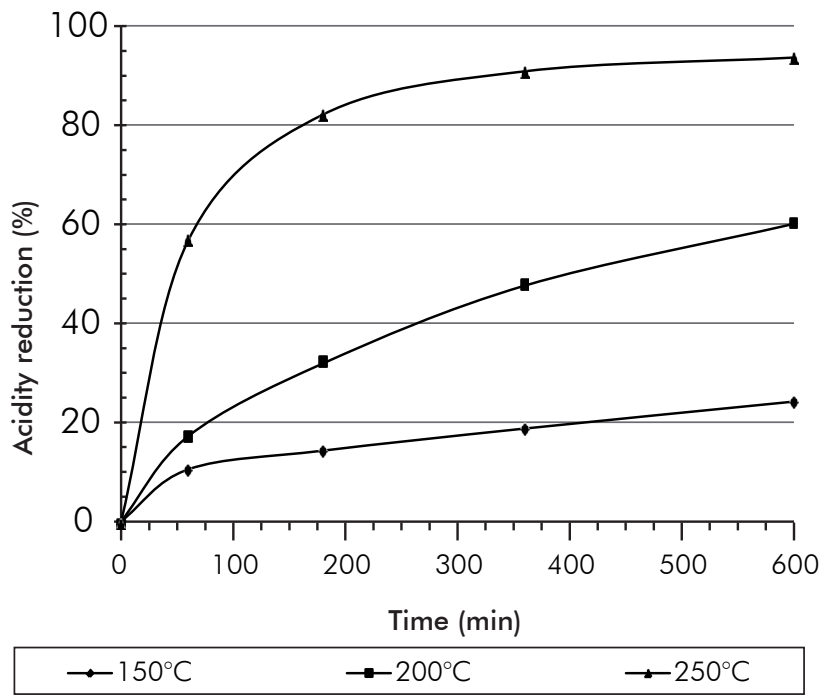

Figure 4 . The effect of temperature on the acidity reduction percentage in the esterification reaction of the naphthenic acids. Molar relation methanol/acid: 20/1.

Esterification causes a displacement in the $C=O$ band of the acids towards $1730-1740 \mathrm{~cm}^{-1}$ aproximately. The relationship between band intesities of these functional groups confirms the reduction in acidity due to esterification of the naphthenic acids.
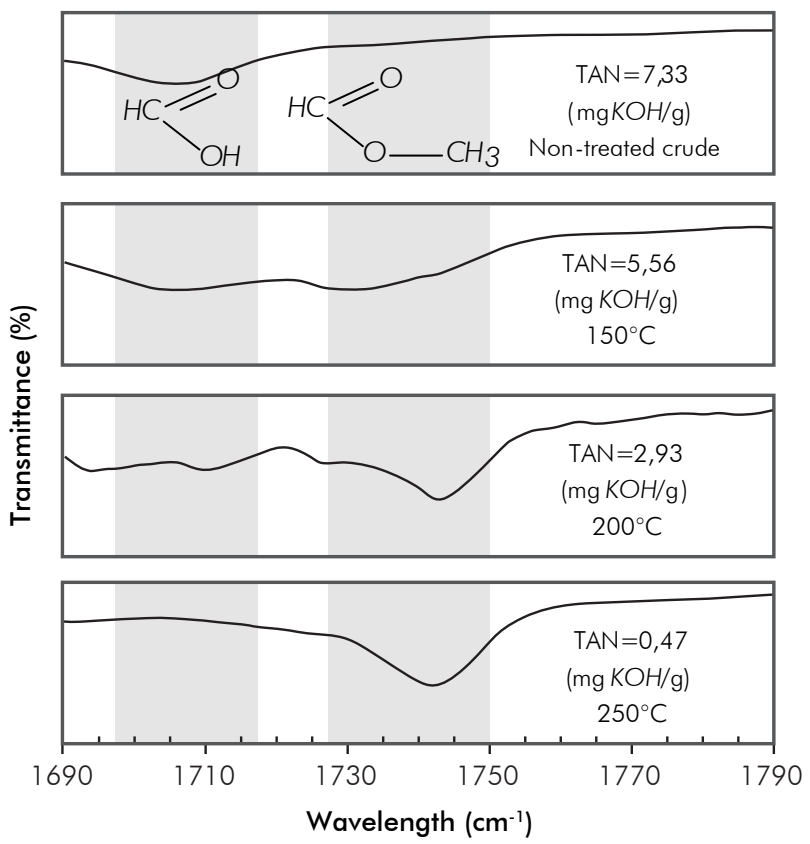

Figure 5. Infrared spectrum of the heavy crude oil before and after the esterification reaction. Reaction time: 600 minutes. Reaction Temperature: $150 ; 200$ and $250^{\circ} \mathrm{C}$. 
Assuming that the molecules of the naphthenic acids are monocarboxylic, it is possible to calculate the concentration of the naphthenic acids during the reaction from the neutralization reaction employed in the determination of the TAN.<smiles>CC1(C(=O)O)CCC(C(=O)O)(C(=O)O[18OH])C1</smiles>

The moles contained in the carboxylic groups in the crude are determined by the following formula:

$\operatorname{mol}_{A N}=\frac{T A N \cdot \rho_{\text {crudo }} \cdot V_{\text {crudo }}}{56000}$

The crude density, $\rho_{\text {crude }}$, expressed in $\mathrm{g} / \mathrm{cm}^{3}$ was specified in Table 1. The crude volume in the reactor, $V_{\text {crude }}$, was $1200 \mathrm{~cm}^{3}$. Figure 6 represents the variation in the acid mole content in the crude during the course of the reaction.

While keeping the molar excess of methanol in mind, and assuming the only reaction in which the acids interfere is esterification, the following rate law for the complete mix reactor may be proposed for batch operation:

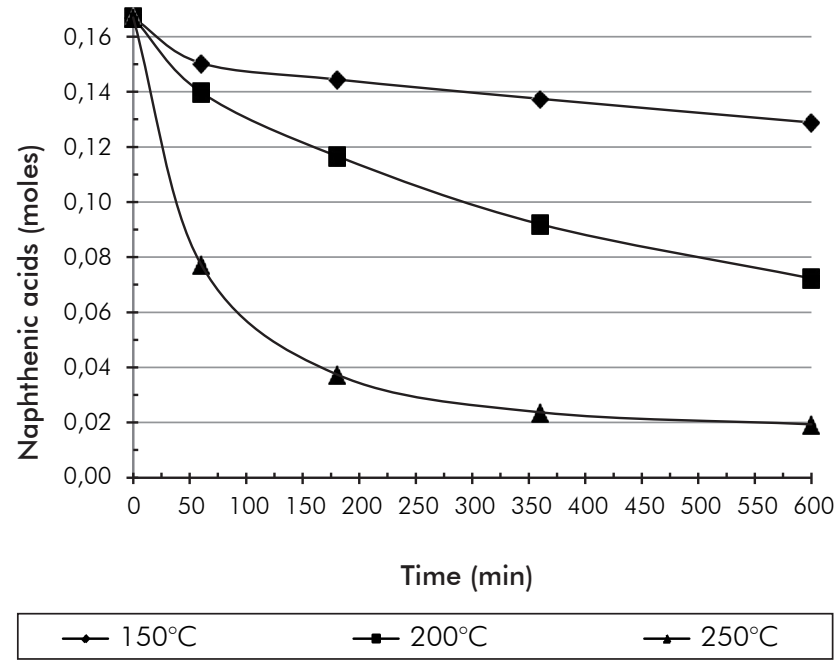

Figure 6. Linearization of the second order velocity reaction for the esterification of naphthenic acids. Molar ratio methanol/acid: 20/1, 600 rpm. $d C_{A N}=k \cdot C_{A N}^{n}$

Where $C_{A N} \mathrm{~mol} / \mathrm{cm}^{3}$, is the concentration of naphthenic acids in the crude, determined from the information in Figure 6, the density and the volume of crude employed; $k$ is the kinetic constant in the reaction, and $n$ is the order of the reaction. The order of the reaction was determined using the integral method, during which an order is assumed and rate law is integrated. For reactions of order $0 ; 1$ or 2 ; the function of concentration $v$ s. time was graphed. The function's linearity was obtained assuming a second order reaction. The results are shown in Figure 7.

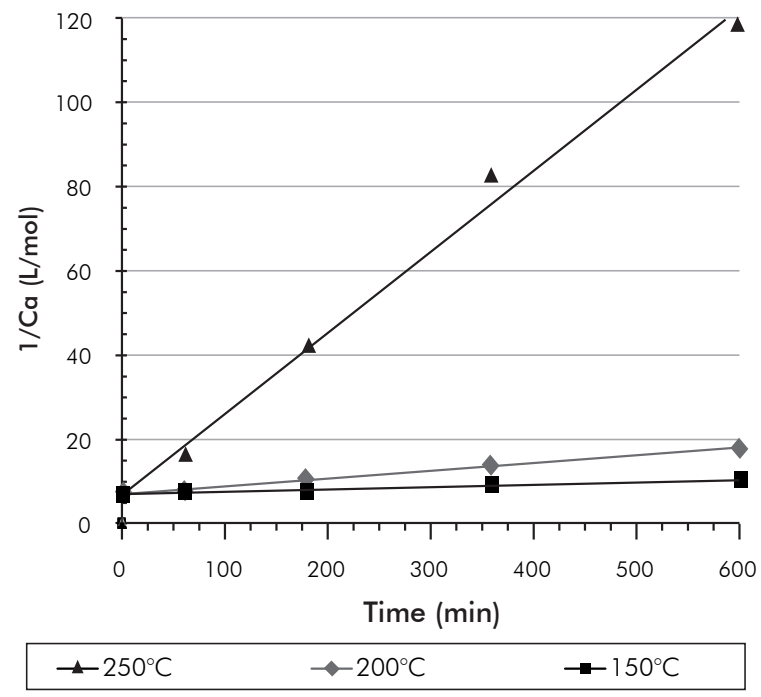

Figure 7. Effects of temperature in the kinetic constant of the esterification reaction of naphthenic acids in a Colombian heavy crude oil.

The slope of the lines obtained in Figure 7 corresponds to the reaction constants for each temperature. The mathematical correlation of the data presented in Figure 7 is specified in Table 3.

Table 3. Mathematical correlation of the rate law for esterification reaction in naphthenic acids.

\begin{tabular}{|l|l|l|}
\hline Temperature ${ }^{\circ} \mathrm{C}$ & Correlation & $R^{2}$ \\
\hline 150 & $y=0,1903 x+8,2467$ & 0,91 \\
\hline 200 & $y=0,0187 x+7,8132$ & 0,99 \\
\hline 250 & $y=0,0036 x+8,0202$ & 0,99 \\
\hline
\end{tabular}


The linearization of the Arrhenius equation (Figure 8) was performed in order to determine the kinetic parameters of the reaction, such as the frequency factor and the activation energy.

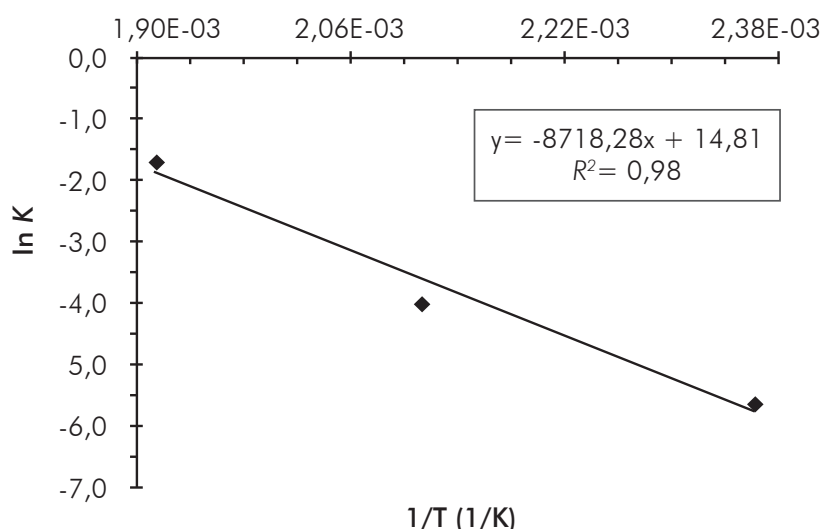

Figure 8. Effects of temperature in the kinetic constant of the esterification reaction of naphthenic acids in a Colombian heavy crude oil.

The slope of the linearized Arrhenius equation corresponds to $-E a / R$, and the intercept to $\ln A, A$ being the frequency factor of the reaction. $R$ is the ideal gas constant $8,3145 \mathrm{~J} / \mathrm{mol} \cdot \mathrm{K}$. The activation energy for the reaction was $72,27 \mathrm{~kJ} / \mathrm{mol}$ and the frequency factor was $2,7087 \times 10^{6} \mathrm{~L} / \mathrm{mol} \cdot \mathrm{min}$. The rate law for the esterification reaction was:

$$
-\frac{d C_{A N}}{d t}=2,7087 \times 10^{6} e^{\left(\frac{-72,27 \times 10^{3}}{R T}\right)} x C_{A N}^{2}
$$

The value of the activation energy obtained during this study is lower than the one determined by other authors for naphthenic acids in light distillation fractions (Wang et al., 2008).
This demonstrates the effect of heterogeneity in the molecular structure of the naphthenic acids in the esterification reaction. Table 4 shows the kinetic and thermodynamic parameters for the rate laws obtained during this study and the ones determined by other researchers.

Figure 9 shows that the corrosion rate for steel as per ASTM A106 Gr.B, in contact with esterified crude, presents a reduction of $90,90 \%$ in comparison to nontreated crude.

This test used esterified crude at $250^{\circ} \mathrm{C}$ with a reaction time of 600 minutes. The standard deviation for the corrosion trials for the treated and non-treated crude were: 0,56 y $0,74 \mathrm{mpy}$, respectively.

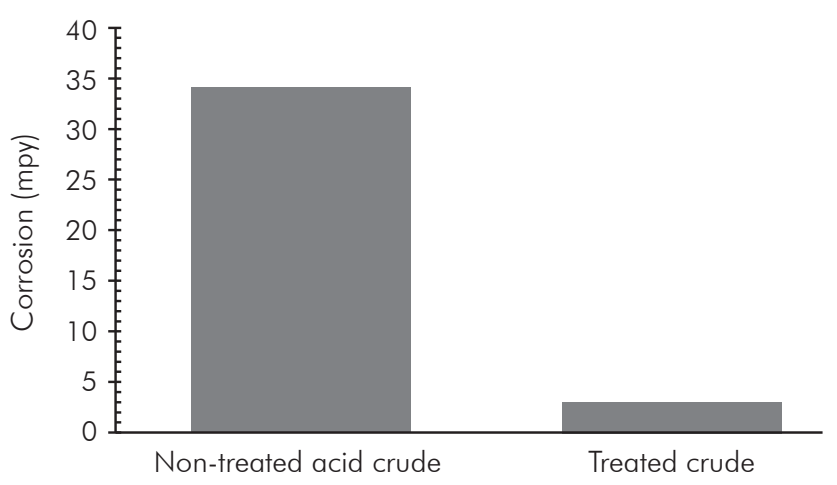

Figure 9. Effects of naphthenic acid esterification in crude upon the corrosion rate of steel as per ASTM A106 Gr.B. Non-treated crude TAN:7,33 mgKOH/g, Esterified crude TAN:0,47 mgKOH/g.

The corrosiveness of high acidity crudes depends on the concentration and types of naphthenic acids (Yépez, 2007; Li \& Luo, 2009). Therefore, it is not necessary to completely reduce the acidity of the crude in order to make it processable without causing damage to the operation equipment.

Table 4. Mathematical correlation of the rate law.

\begin{tabular}{|l|l|l|l|l|}
\hline Conditions & TAN (mgKOH/g) & API & $\begin{array}{l}\text { Frequency Factor } \\
\text { (L/mol·min) }\end{array}$ & $\begin{array}{l}\text { Activation } \\
\text { Energy (kJ/mol) }\end{array}$ \\
\cline { 2 - 6 } Without catalyst-Diesel (Wang et al., 2008) & \multirow{2}{*}{ W,69 } & & $7,15 \times 10^{14}$ & 153,7 \\
\hline With catalyst (SnO) Diesel (Wang et al., 2008) & & 19,11 & $1,70 \times 1011$ & 104,2 \\
\hline Colombian heavy crude oil & 7,33 & 11,30 & $2,71 \times 10^{6}$ & 72,27 \\
\hline
\end{tabular}




\section{CONCLUSIONS}

- The kinetics of the esterification process of naphthenic acids in Colombian heavy crude oil using methanol and in the absence of a catalyst at temperatures between $150-250^{\circ} \mathrm{C}$ was adjusted to a second order rate law with respect to the concentration of naphthenic acids.

- The activation energy of the esterification reaction of naphthenic acids in Colombian heavy crude oil of $72,27 \mathrm{~kJ} / \mathrm{mol}$, is lower than that calculated by other authors (Wang et al., 2008). These authors used naphthenic acids from a vacum distillation fraction, which indicates that they were acids with a higher boiling point and molecular weight. This demonstrates that the influence of the structural and physical-chemical parameters of the acids upon kinetic and thermodynamic aspects of the esterification reaction and the rate law calculated in this investigation represent the global kinetics of reaction for a heterogeneous mixture of naphthenic acids present in Colombian crude.

- The influence of the structural characteristics of the naphthenic acids upon reaction kinetics was not evaluated during this investigation. However, the comparison between the obtained results and those determined by Wang et al., (2008) demonstrate that naphthenic acids with a lower molecular weight and boiling point are more reactive during esterification.

- Based on the structural characterization of the naphthenic acids extracted from the crude, it was determined that the carboxylic groups are located in low conjugation carbons. The presence of methylenes in carbon chains were identified by means of the infrared spectrum. It was determined that naphthenic acids in Colombian heavy oil present a molecular weight distribution between 180 and $2400 \mathrm{~g} / \mathrm{mol}$, while the greatest portion of the fraction had a molecular weight above $400 \mathrm{~g} / \mathrm{mol}$.

- The aromaticity factor of the extracted acid fraction was $8,95 \%$, as determined by the proton RMN. The infrared spectrum of the esterified crude shows that the reduction in acidity is related to the formation of the respective esters.

- The corrosion tests demonstrated a reduction of $90,90 \%$ in the corrosion rate of carbon steel per ASTM 106 Gr.B, after esterification treatment.

- Bearing in mind that this investigation determined the global esterification kinetics of a heterogeneous group of molecules with different reactivity, future work is necessary in order to optimize the esterification reaction towards the conversion of the more corrosive acids.

\section{ACKNOWLEDGMENTS}

The authors would like to express their gratitude with Ecopetrol S.A. - Instituto Colombiano del Petróleo (ICP) and the Universidad Industrial de Santander (UIS), for their technical and economic support during the course of this investigation.

\section{REFERENCES}

Alvisi, P. \& Lins, V. (2011). An overview of naphthenic acid corrosion in a vacuum distillation plant. Engin. Failure Anal., 18 (5), 1403-1406.

ASTM A106 / A106M - 11 Standard Specification for Seamless Carbon Steel Pipe for High-Temperature Service. ASTM International, West Conshohocken, PA, 2006.

ASTM Standard D 287. Test Method for API Gravity of Crude Petroleum and Petroleum Products (Hydrometer Method). ASTM International, West Conshohocken, PA, 2006.

ASTM Standard D 664. Test Method for Acid Number of Petroleum Products by Potentiometric Titration. ASTM International, West Conshohocken, PA, 2001.

ASTM Standard G 1. Practice for Preparing, Cleaning, and Evaluating Corrosion Test Specimens. ASTM International, West Conshhocken, PA, 1990.

ASTM Standard D 1552. Test Method for Sulfur in Petroleum Products (High-Temperature Method). ASTM International. West Conshohocken, PA, 2008. 
ASTM Standard D 5002. Test Method for Density and Relative Density of Crude Oils by Digital Density Analyzer. ASTM International. West Conshohocken, PA, 2010.

Biryukova, V., Fedorak, P. \& Quideau, S. (2007). Biodegradation of naphthenic acids by rhizosphere microorganisms. Chemosphere, 67 (10), 2058-2064.

Borges, B. \& Acevedo, S. (2007). Caracterización estructural de distintas fracciones aisladas del crudo extrapesado Carabobo. Revista Latinoamericana de Metalurgia y Materiales, 27 (2), 83-94.

Dettman, H., Li, N. \& Luo, J. (2009). Refinery corrosion, organic acid structure and athabasca bitumen. NACE International, Paper 09336.

Dettman, H., Li, N., Luo, J. \& Wickramasinghe, D. (2010). The influence of naphthenic acid and sulphur compound structure on global crude corrosivity under vacuum distillation conditions. $N A C E$. Northem Area Western Conference.

Ding, L., Rahimi, P., Hawkins, R., Bhatt, S. \& Shi, Y. (2009). Naphthenic acid removal from heavy oils on alkaline earth-metal oxides and $\mathrm{ZnO}$ catalysts. Applied Catalysis A: General, 371 (1-2), 121-130.

dos Santos, R., Mohamed, R., Bannwart, A. \& Loh, W. (2006). Contact angle measurements and wetting behavior of inner surfaces of pipelines exposed to heavy crude oil and water. J. of Petrol. Science and Engin., 51 (1), 9-16.

Gaikar, V. \& Maiti, D. (1996). Adsorptive recovery of naphthenic acids using ion-exchange resins. Reactive and Functional Polymers, 31 (2), 155-164.

Hoeiland, S., Barth, T., Blokhus, A. M. \& Skauge, A. (2001). The effect of crude oil acid fractions on wettability as studied by interfacial tension and contact angles. J. Pet. Sci. Eng., 30 (2), 91 - 103.

Kane, R \& Cayard, M. (2002). A comprehensive study on naphthenic acid corrosion. Corrosion. Paper 02555.

Messer, B., Beaton, M., Tarleton, B. \& Phillpis, T. (2004). New theory for naphthenic acid corrosivity of athabasca oilsands crudes. NACE. Paper 04634.

Qu, D. \& Zheng, Y. (2006). High temperature naphthenic acid corrosion and sulphidic corrosion of Q235 and 5Cr1/2Mo steels in synthetic refining media. Corrosion Science, 48 (8), 1960-1985.

Rikka, P. (2007). Spectrometric identification of naph- thenic acids isolated from crude oil. Thesis postgrademaster in science. Department of chemistry \& biochemistry, Texas State University, San Marcos, Texas, U.S.A., 67 pp.

Sartori, G. (2001). U.S. Patent No. 6,252,305. Annandale, NJ (US). Patent and Trademark Office.

Simon, S., Nordgård, E., Bruheim, P. \& Sjöblom, J. (2008). Determination of C80 tetra-acid content in calcium naphthenate deposits. J. of Chromatography A, 1200 (2), 136-143.

Wang, Y., Chu, Z., Qiu, B., Liu, C. \& Zhang, Y. (2006). Removal of naphthenic acids from vacuum fraction oil with an ammonia solution of ethylene glycol. Fuel, 85 (17-18), 2489-2493.

Wang, Y., Liu, Y. \& Liu, C. (2008). Kinetics of the esterification of low-concentration naphthenic acids and methanol in oils with or without $\mathrm{SnO}$ as a catalyst. Energy \& Fuels, 22 (4), 2203-2206.

Wang, Y., Sun, X., Liu. Y. \& Liu. C. (2007). Removal of naphthenic acids from a diesel fuel by esterification. Energy \& Fuels, 21 (2), 941-943.

Yépez, O. (2007). On the chemical reaction between carboxylic acids and iron, including the special case of naphthenic acid. Fuel, 86 (7-8), 1162-1168.

Zhang, A., Ma, Q., Wang, K., Liu, X. Shuler, P. \& Tang, Y. (2006). Naphthenic acid removal from crude oil through catalytic decarboxylation on magnesium oxide. Applied Catalysis A: General, 303 (1), 103-109. 


\begin{tabular}{|rl|}
\hline & \multicolumn{1}{c|}{ NOTATION } \\
$C_{A N}$ & Naphthenic acid concentration, $\mathrm{mol} / \mathrm{cm}^{3}$ \\
$k$ & Kinetic constant, $\mathrm{L} / \mathrm{mol} \cdot \mathrm{min}$ \\
$n$ & Kinetic reaction order \\
$T A N$ & Total Acid Number, $\mathrm{mg} \mathrm{KOH} / \mathrm{g}$ \\
$\rho$ & Density, $\mathrm{g} / \mathrm{cm}^{3}$ \\
$V$ & Volume, $\mathrm{cm}^{3}$ \\
$R$ & Ideal gas constant, $\mathrm{J} / \mathrm{mol} \cdot \mathrm{K}$ \\
$T$ & Temperature, $\mathrm{K}$ \\
$E a$ & Activation energy, $\mathrm{kJ} / \mathrm{mol}$ \\
& \\
\hline
\end{tabular}


